\title{
PERLINDUNGAN HUKUM TERHADAP FRANCHISEE AKIBAT PEMUTUSAN SEPIHAK DALAM PERJANJIAN FRANCHISE
}

\author{
I Gusti Ngurah Md Rama Andika, Ni Luh Made Mahendrawati, Ida Ayu Putu Widiati \\ Fakultas Hukum, Universitas Warmadewa, Denpasar-Bali, Indonesia \\ ramaandika632@gmail.com, made.mahendrawati@gmail.com, widiati_dayu@yahoo.co.id
}

\begin{abstract}
Abstrak
Dalam pelaksanaan perjanjian franchise tidak jarang perjanjian tersebut tidak terlaksana karena terjadi pemutusan secara sepihak oleh franchisor. Mengingat franchisee dalam perjanjian franchise tersebut dalam posisi yang lebih lemah jika terjadi pemutusan sepihak akan mengalami kerugian yang besar. Namun peraturan perundang-undangan belum ada pengaturan yang jelas untuk perlindungan franchisee yang mengalami pemutusan sepihak yang nyata-nyata mengalami kerugian. Tujuan penelitian ini untuk menganalisa perjanjian franchise boleh diputus secara sepihak oleh franchisor dan perlindungan hukum franchisee terhadap dalam pemutusan perjanjian franchise secara sepihak oleh franchisor. Penelitian ini menggunakan metode penelitian hukum normatif dengan menggunakan bahan hukum primer, dengan jenis pendekatan yang digunakan adalah pendekatan perundang-undangan, pendekatan kasus dan pendekatan konseptual. Sumber hukum kemudian dianalisis secara sistematis. Berdasarkan hasil penelitian dapat disimpulkan bahwa pada dasarnya perjanjian franchise tidak dapat di putus secara sepihak kecuali syarat batal yang dicantumkan dalam kontrak telah dipenuhi dan perlindungan hukum bagi franchisee terhadap kerugian yang dialaminya dapat di tuntut ganti kerugian berdasarkan wanprestasi.
\end{abstract}

Kata Kunci: Franchisee, Pemutusan Sepihak, Perlindungan Sepihak

\begin{abstract}
In the implementation of a franchise agreement, it is not uncommon for the agreement not to be implemented due to a unilateral termination by the franchisor. Considering that the franchisee in the franchise agreement is in a weaker position, in the event of a unilateral termination, it will suffer a large loss. However, in the laws and regulations, there are no clear arrangements for the protection of franchisees who experience unilateral termination who actually experience losses. The purpose of this study is to analyze the franchise agreement may be terminated unilaterally by the franchisor and the legal protection of the franchisee against the unilateral termination of the franchise agreement by the franchisor. This study uses normative legal research methods using primary legal materials, with the types of approaches used are statutory approaches, case approaches and conceptual approaches. Legal sources are then analyzed systematically. Based on the results of the study, it can be concluded that basically the franchise agreement cannot be terminated unilaterally unless the void conditions stated in the contract have been fulfilled and legal protection for the franchisee against the losses he has suffered can be sued for compensation based on default.
\end{abstract}

Keywords: Franchisee, Unilateral Termination, Franchise Agreement

\section{PENDAHULUAN}

Perekonomian yang saat ini bertumbuh cukup pesat, memicu adanya berbagai macam persaingan bisnis atau usaha di luar sana, yang tak dapat terelakkan. Dengan adanya perlindungan terkait pendaftaran hak kekayaan intelektual atau HAKI dapat membantu dalam mencegah persaingan usaha yang tak sehat serta berdampak positif untuk elakukan peningkatan dalam mengembangkan perekonomian serta membantu dalam percepatan pembangunan yang ada di negara ini. Sebut saja salah satu yang terkenal atau populer belakangan ini mengenai bisnis waralaba atau franchise, yang mana perkembangannya sangatlah besar (Margono, 2010).

Menurut (Aidi \& Farida, 2019) perkembangan bisnis waralaba (franchise) telah berkembang dengan pesat dan menjadi kekuatan baru bagi sektor ekonomi domestik di Indonesia. Franchise merupakan suatu bentuk kerjasama yang terjalin terkait dengan investasi dalam membangun suatu bisnis, untuk itu kerjasama yang terjalin antara para pihak di dalamnya berperan penting terhadap keberhasilan dari bisnis yang dijalankan tersebut. Hubungan (Widjaja, 2002). Dalam kerjasama bisnis 
waralaba atau franchise ini, para pihak yang ada di dalamya hampir sama dengan perjanjian pada umumnya dimana ada pihak pemberi hak untuk melakukan pemanfaatan atau penggunaan atas suatu hak kekayaan intelektual yang mana disebut franchisor, sedangkan pihak yang menerima hak atau pengguna dan pemanfaat dari kekayaan intelektual tersebut disebut sebagai franchisee. Para pihak ini bisa berbentu badan hukum atau perseorangan. Franchising (pewaralabaan) pada hakekatnya adalah sebuah konsep pemasaran dalam rangka memperluas jaringan usaha secara cepat. Dengan demikian Franchising adalah salah satu cara yang sama kuat dan strategisnya dengan cara konvensional dalam mengembangkan usaha (Effendi, 2021).

Dari hasil kerjasama melalui perjanjian yang dibuat ini, nantinya menimbulkan hubungan hukum bagi para pihak tersebut yang mana penaturannya dapat dilihat pada Peraturan Menteri Perdagangan Republik Indonesia tentang Waralaba Nomor 53/M-DAG/PER/8/2012 yaitu tepatnya dalam pasal 5. Selain dalam ketentuan pada peraturan tersebut, beberapa kebijakan juga telah dikeluarkan untuk mengatur perbuatan hukum ini sebut saja dengan dikeluarkannya Peraturan Pemerintah Republik Indonesia tentang franchise Nomor 42 tahun 2007 serta ada pula Keputusan Peraturan Menteri Perindustrian dan Perdangan Ruplik Indonesia yang dikeluarkan pada 30 Juli 1997 tentang tata cara pelaksanaan pendaftaan usaha waralaba Nomor 259/MPP/Kep/7/1997 dan tentang tata cara penyelenggaraannya yaitu No.31/M-DAG/PER/8/2008. Begitu pula pengaturannya dapat kita peroleh dalam Kitab Undang-Undang Hukum Perdata tepatnya di bagian Buku ke-3, yang mengatur bahwa bisnis franchise ini termasuk menganut sistem terbuka, sehingga bebas bagi siapapun yang ingin membuat atau melakukan suatu perjanjian, asalkan tak melakukan hal-hal yang undang-undang larang untuk lakukan, hal ini selaras dengan pasal 1338 ayat (1) dalam KUH Perdata.

Bisnis franchise atau waralaba di Indonesia merupakan salah suatu usaha yang sangat menarik bagi pelaku usaha namun dengan perkembangan yang ada dalam rangka memberikan perlindungan hukum bagi kedua belah pihak antara franchisor (pemberi waralaba) dan franchisee (penerima waralaba) tidaklah cukup pengaturannya melalui peraturan pemerintah saja sehingga perlu dibuat suatu undang-undang tentang waralaba (Lannemey, 2015). Menurut (Zulhelmi \& Mufidi, 2018) apabila pada pelaksanaan perjanjian waralaba salah satu pihak memutuskan perjanjian secara sepihak dan terjadi perselisihan hal pertama yang dilakukan lewat jalan musyawarah mufakat, dan apabila persengketaan tersebut tidak berhasil mencapai kesepakatan maka kedua belah pihak sepakat dan setuju untuk menyelesaikan dengan melapor ke pengadilan setempat. Adapun terkait pemutusan perjanjian, pada Pasal 6 Peraturan Pemerintah Nomor 42 Tahun 2007 tentang Waralaba dan Pasal 8 Peraturan Menteri Perdagangan Nomor 53/M-DAG/PER/8/2012 tentang Penyelenggaraan Waralaba menjelaskan mengenai pemutusan waralaba sepihak oleh franchisor sebelum masa berlaku perjanjian berakhir (Nisa et al., 2021).

Berdasarkan pemaparan diatas, tujuan penelitian ini untuk menganalisa perjanjian franchise boleh diputus secara sepihak oleh franchisor dan perlindungan hukum franchisee terhadap dalam pemutusan perjanjian franchise secara sepihak oleh franchisor.

\section{METODE PENELITIAN}

Dalam penyusunan setiap penelitian ini digunakan metode normatif, yang mana perujukannya berdasarkan pada pendekatan perundang-undangan, pendekatan kasus, serta melalui pendekatan konseptual. Ada beberapa suber bahan hukum baik primer atau sekunder yang digunakan seperti Kitab Undang-Undang Hukum Perdata, Peraturan Pemerintah Republik Indonesia tentang Waralaba Nomor 42 Tahun 2007 serta Peraturan Menteri Perdagangan Republik Indonesia tentang Penyelenggaraan Waralaba Nomor 53/M- DAG/PER/8/2012. Selain itu penggunaan buku-buku literatur, jurnal-jurnal terkait juga membantu penelitian ini. Sumber hukum kemudian dianalisis secara sistematis yaitu dengan menguraikan, menjelaskan dan menggambarkan sesuai dengan permasalahan yang erat kaitannya dengan penelitian ini.

\section{HASIL DAN PEMBAHASAN}

\section{Perjanjian Franchise Boleh Diputus Secara Sepihak oleh Franchisor}

Sama seperti perjanjian pada uumnya, dalam kerjasama untuk membangun bisnis waralaba ini juga diperlukan syarat, yang mana berpedoman pada KUH Perdata dalam pasal 1320 mengenai perjanjian yang dianggap sah dan legal untuk dilakukan. Syarat pertama, mengenai kesepakatan yaitu baik si pemberi waralaba (franchisor) maupun penerima waralaba (franchisee) haruslah sepakat dahulu untuk 
melakukan bisnis ini. Ini ditandai dengan adanya kebebasan kehendak, tanpa paksaan dan kekangan atau pun tekanan dari luar kehendaknya. Syarat kedua, mengenai cakapnya para pihak, mengingat hal ini terkait pada hak dan kewajiban para pihak, maka cakap merupakan hal yang wajib, karena nantinya peru pertanggung jawaban dalam membuat suatu perjanjian, sehingga para pihak mampu mengemban dan melaksanakan hak dan kewajiban tersebut sebagaimana ketentuan peraturan perundang-undangan mengaturnya. Syarat ketiga, mengenai obyek dari perjanjian atau kerjasama ini, dalam perjanjian waralaba juga harus ditentukan apa obyek yang diperjanjikan, sehingga jelas tertuang di dalamnya, untuk itu kepastian dari hukum di dalamnya mengikat dengan jelas pula nantinya. Obyek ini dapat benda yang sudah ada atau yang akan ada sifatnya. Syarat keempat, adalah menegnai klausa halal, yang mana tak ada larangan dari peraturan perundang-undangan yang ada, seperti halnya haruslah beritikad baik, tak melanggar apa yang tertera dalam aturan hukum yang berlaku, dan pastinya tak merugikan para pihak pihak lain bahkan negara sekalipun.

Perolehan hak untuk menggunakan serta memanfaatkan suatu merek dagang yang merupakan bagian dari hak atas kekayaan intelektual yang telah didaftarkan merupakan bentuk isi dari kerjasama yang tertuang dalam perjanjian waralaba atau franchise antara franchisor dengan franchisee. Di dalamnya juga mengatur mengenai hak dan kewajiban para pihak dalam melakukan pengolahan dari merek dagang tersebut. Nantinya royalti dan pembayaran akan diperoleh oleh si pemberi hak dari pengguna hak merek dagang yang telah berizin tersebut.

Karena tak dapat kita jumpai dalam Kitab Hukum Perdata, bentuk perjanjian franchise ataau waralaba ini termasuk perjanjian khusus, yang mana tak lepas dari pasal 1338 yang memberikan kebebasan dalam melakukan psuatu perjanjian, sehingga secara implisit dapat ditafsirkan pengaturannya secara umum di Kitab Hukum Perdata. Seperti yang telah disebutka sebelumnya, kerjasama bisnis waralaba atau franchise ini merupakan hampir sama dengan perjanjian pada umumnya dimana ada pihak pemberi hak untuk melakukan pemanfaatan atau penggunaan atas suatu hak kekayaan intelektual yang mana disebut franchisor, sedangkan pihak yang menerima hak atau pengguna dan pemanfaat dari kekayaan intelektual tersebut disebut sebagai franchisee. Para pihak ini bisa berbentu badan hukum atau perseorangan. Adapun bentuk hak yang diberikan yaitu seperti pemberian lisensi atas suatu merek dagang.

Pemberian lisensi atas suatu merek dagang ini dilakukan untuk kegiatan produksi atau pun pemasaran bisnis tersebut yang ana dengan jangka waktu yang telah ditentukan kedua pihak. Pengawasan wajib dilakukan dan merupakan hak franchisor, sedangkan franchisee wajib mebayar royalti kepada franchisor, sebagimana isi dari perjanjian yang dibuat dan disepakati (H.S, 2005). Sebagaimana dalam Peraturan Pemerintah tentang waralaba Nomor 42 Tahun 2007 tepatnya dalam pasal 4 ayat (1), bahwa perjaniian franchise ini dilakukan atau dibuat secara tertulis bentuknya. Dan apabila terdapat istilah asing nantinya, wajib dilakukan penerjemahan ke dalam bahasa ibu kita bahasa Indonesia. Jangka waktu dalam perjanjian waralaba pada umunya minimal 5 tahun lamanya, ini pun dapat diperpanjang sesuai kehendak dari para pihak sendiri dan kesepakatan mereka. Ini dianggap sebaagi waktu yang cukup untuk elihat dan memantau dahulu kerjasama mereka apakah berjalan dengan baik dan menghasilkan keuntungan atau tidak.

Seperti perjanjian lainnya, wanprestasi juga tak dapat dihindari apabila terdapat pelanggaran isi dari perjanjian yang dilakukan oleh salah satu pihak. Untuk itu tuntutan untuk ganti kerugian tak dapat dihindarkan dari pihak yang dirugikan. Karena berisikan mengenai pemberian hak terkait kekayaan intelektual yaitu seperti lisensi atau merek dagang maka wajib perjanjian waralaba dilakukan pendaftaran melalui Kementrian Perdagangan. Pengaurannya dapat dijumpai dalam PP waralaba yaitu dalam pasal 11 ayat (2).

Pemutusan perjanjian secara sepihak oleh pihak franchisor tak dapat diterima mengingat hal tersebut menimbulkan kerugian bagi franchisee, sehingga setiap pemutusan perjanjian tersebut haruslah dimintakan ke pengadilan, agar dapat mendapat syarat legalnya, ini pun didukung dengan adanya rumusan pasal 1266 ayat (2) serta PP tentang waralaba Nomor 42 Tahun 2007 pada pasal 5 huruk (k). Ini beda halnya dengan wanprestasi dilakukan jika pemutusan sepihak dilakukan tanpa adanya syarat atau klausula yang tercantum di isi perjanjian. 


\section{Perlindungan Hukum Franchisee Terhadap Dalam Pemutusan Perjanjian Franchise Secara Sepihak oleh Franchisor}

Disetiap perjanjian pasti terdapat jangka waktu lama dari berlakunya suatu perjanjian kapan ulai berlaku dan kapan berakhirnya, hingga cara-cara atau syarat berakhirnya. Ini dapat dilakukan perpanjangan masa atau jangka waktu tergantung kehendak atau kesepakatan para pihak. Ini juga berlaku dalam perjanjian franchise. Namun bagaimana bila terjadi pemutusan kontrak secara sepihak oleh salah satu pihak, yang dala hal ini dari pihak franchisor sebagai pemberi hak, ini yang menjadi polemik, karena pihak penguasa merek yang melakukannya, tentu akan menjadi bencana bagi pihak franchisee.

Perjanjian merupakan hubungan antara para pihak di dalamnya yang sepakat mengikatkan diri untuk melakukan sesuatu atau tidaknya yang berpedoman pada syarat sahnya perjanjian itu sendiri pada pasal 1320 KUH Perdata. Setiap perjanjian harus ditaati dan dianggap sebagaimana undangundang bagi para pihak di dalamnya, ini juga sejalan pendapat Abdulkadir Muhammad, yang merujuk pada pasal $1338 \mathrm{KUH}$ Perdata, mengingat perjanjian tersebut telah dibuat secara sah sehingga kekuatan hukum mengikatnya pun sama kuatnya. Untuk itu tidak dapat dilakukn penarikan perjanjian tersebut atau pemutusan sepihak, melainkan harus atas kesepakatan bersama dan dimintakan untuk diputus oleh pengadilan (Muhammad, 1982).

Pada hakikatnya, pemutusan suatu perjajian oleh satu pihak tidak dibenarkan dan tidak diperbolehkan, terkecuali dalam perjanjian tersebut terdapat klausul mengenai hal tersebut. Namun dalam pengaturannya jika dilihat rumusan KUH Perdata Pasal 1266 ayat (1) bahwa syarat batal tersebut ada walau tak tersurat dalam isi perjanjian, dengan catatan bahwa perjanjian timbal balik tersebut terdapat pihak yang tak menjalankan kewajibannya sebagaimana diatur dalam isi perjanjian. Setiap pemutusan perjanjian tersebut haruslah dimintakan ke pengadilan, agar dapat mendapat syarat legalnya, ini pun didukung dengan adanya rumusan pasal 1266 ayat (2) serta PP tentang waralaba Nomor 42 Tahun 2007 pada pasal 5 huruk (k). Ini beda halnya dengan wanprestasi dilakukan jika pemutusan sepihak dilakukan tanpa adanya syarat atau klausula yang tercantum di isi perjanjian.

Ketentuan pasal 8 Peraturan Menteri Perdagangan tentang Penyelenggaraan Waralaba mengatur mengenai tidak dapatnya dilakukan penunjukan untuk franchisee baru dalam wilayah sama dalam hal pemutusan kontrak dilakukan secara sepihak sebelum selesainya atau berakhirnya jangka waktu kontrak, ini juga karena harus ada penyelesaian berupa kesepakatan terlebih dahulu antara para pihak dengan enunggu pula adanya putusan yang inkracht dari pengadilan terkait permaslaahan ini. Dari ketentuan tersebut, maka pelarangan pemutusan sepihak suatu perjanjian waralaba memang benar adanya mengingat itu merupakan bentuk tindakan sewenang-wenang, seperti dalam penggantian franchisee oleh pihak lain, itu semua tak dapat dibenarkan. Karena jika belum adaya putusan dari penagdilan mengenai pemutusan perjajian tersebut, jadi tidak dapat dilakukan penggantian franchisee atau penerima hak.

Perbuatan ketika melakukan peniadaan atas prestasi yang menjadi kewajibannya merupakan bentuk wanprestasi dalam hukum perjanjian, itu artinya suatu hal yang semestinya dilakukan dan dipenuhi, namun kenyataannya tak terpenuhi dengan semestinya oleh pihak lainnya. Sedangkan menurut alhli lainnya yaitu Yahya Harahap, waktu yang tak sesuai dari isi perjanjian dalam melaksanakan pemenuhan prestasi juga merupakan suatu wanprestasi. Dari sini timbul balasan berupa pembayaran ganti kerugian atas perbuatan tersebut kepada pihak yang dirugikan karena wanprestasi tersebut. Hal ini merupakan suatu keharusan selain itu dapat pula dilakukan penuntutan pembatalan perjanjian (Prodjodikoro, 1999).

Walaupun telah diatur dalam pasal 8 Peraturan Menteri Perdagangan tentang penyelenggaraan waralaba Nomor 53/M-DAG/PER/8/2012 mengenai kondisi apabila terjadi pemutusan kontrak secara sepihak, namun di dalamnya masih belum memberikan perlindungan yang berarti bagi pihak yang dirugikan akibatnya. Jangkauan perlindungan masih belum terasa bagi pihak franchisee. Karena kerugian yang dirasa pastinya cukup besar, maka tak ayal franchise melakukan penuntutan terkait ganti rugi tersebut yang dirasa masih kurang dari franchisor.

Dikatakan melakukan wanprestasi ketika pemutusan kontrak waralaba secara sepihak ini dilakukan sebelum waktu seharusnya berakhirnya perjanjian tersebut yang mana telah disepakati para pihak saat pembuatan kontrak. Untuk itu, pelanggaran isi dari kontrak atau perjanjian seperti itu merupakan bentuk wanprestasi, karena menimbulkan kerugian pada pihak franchisee, dan kewajiban bagi franchisor membayar ganti kerugian kepada franchisee merupakan kewajiban yang harus 
dipenuhi. Hal ini merujuk pada pasal 1243 KUHPerdata, apabila terdapat wanprestasi oleh salah satu pihak maka pihak lainnya wajib melakukan penggantian biaya kerugian untuk itu, bahkan bunganya juga.

\section{SIMPULAN DAN SARAN \\ 1. Simpulan}

Pada dasarnya dalam pemutusan perjanjian franchise secara sepihak oleh franchisor secara khusus harus memenuhi klausul syarat putus yang telah terpenuhi yang diatur dalam Peraturan Pemerintah tentang Waralaba dan harus tunduk pada Kitab Undang- Undang Hukum Perdata (KUHPerdata). Dalam perjanjian waralaba memuat tata cara perpanjangan, pengakhiran, dan pemutusan perjanjian. Dalam tercapainya tujuan dari perjanjian franchise yang sama-sama menguntungkan perjanjian franchise didukung oleh pihak pihak yang bersangkutan dimana para pemberi waralaba dan penerima waralaba benar benar memahami serta melaksanakan isi perjanjian yang telah dikehendaki dan dapat memutuskan perjanjian franchise dengan adanya kesepakatan kedua belah pihak baik dengan musyawarah atau melalui keputusan pengadilan. Perlindungan hukum bagi para pihak dalam pelaksanaan perjanjian franchise merupakan salah satu aspek penting dalam mengawasi perlindungan hukum kepada para pihak dari perbuatan merugikan pihak lain. Dalam hal terjadinya pemutusan perjanjian sepihak yang dilakukan oleh franchisor sebelum berakhirnya jangka waktu perjanjian yang telah disepakat bagi franchisee dapat menuntut kerugian yang dialaminya dengan tuntutan ganti kerugian karena wanprestasi. Dalam penyelesaian sengketa oleh para pihak yang terlibat dapat melalui cara musyawarah terlebih dulu dengan memberikan teguran atau somasi.

\section{Saran}

Dalam rangka menjamin perkembangan perekonomian di Indonesia, maka hendaknya pembentuk undang-undang segera membuat undang-undang yang mengatur tentang franchise yang dapat membatasi pembatasan sepihak yang didasarkan pada franchisee tidak melakukan kewajiban harus dibatasi hanya dengan franchisee tidak melakukan kewajiban karena ada faktor kesengajaan sehingga jika franchisee tidak melakukan kewajibanya karena faktor perkembangan ekonomi syarat batal tidak dapat dipergunakan. Untuk menjamin tercapainya tujuan dari perjanjian franchise, hendaknya kepada franchisor maupun franchisee benar-benar memahami isi perjanjian yang dibuat maupun peraturan perundang- undangan yang berlaku terhadap franchise itu sendiri sehingga kedua belah pihak dapat melaksanakan isi dari perjanjian tersebut sesuai denga apa yang dikehendaki.

\section{DAFTAR PUSTAKA}

Aidi, Z., \& Farida, H. (2019). Perlindungan Hukum Para Pihak Dalam Perjanjian Waralaba Makanan. Jurnal Cendekia Hukum, 4(2), 207-230.

Effendi, A. (2021). Perlindungan Hukum Terhadap Franchisor dan Franchisee Pada Usaha Waralaba Dalam Perspektif Hak Kekayaan Intelektual (Studi Aspek Hukum Perjanjian). Jurnal Inovasi Penelitian, 2(2), 533-547.

H.S, S. (2005). Perkembangan Hukum Kontrak Innominaat di Indonesia. Sinar Grafika, Jakarta.

Lannemey. (2015). Akibat Hukum Pemutusan Perjanjian Franchise Secara Sepihak oleh Franchisor Sebelum Berakhirnya Kontrak. Lex Privatum, 8(1), 161-170.

Margono, S. (2010). Aspek Hukum Komersialisasi Aset Intelektual. Nuansa Aulia, Bandung.

Muhammad, A. (1982). Hukum Perikatan. Alumni, Bandung.

Nisa, S., Suratman, \& Ayu, I. K. (2021). Perlindungan Hukum Bagi Franchisee Terhadap Pemutusan Perjanjian yang disebabkan Franchisor Pailit. Dinamika, Jurnal Ilmiah Ilmu Hukum, 27(6), 860875.

Prodjodikoro, W. (1999). Asas-asas Hukum Perjanjian. Mandar Maju, Bandung.

Widjaja, G. (2002). Lisensi atau Waralaba Suatu Panduan Praktis. PT. Raja Grafindo Persada, Jakarta.

Zulhelmi, M. I., \& Mufidi, M. F. (2018). Perlindungan Hukum terhadap Penerima Waralaba Akibat Pemutusan Perjanjian Waralaba Secara Sepihak oleh Pemberi Waralaba Dihubungkan dengan Peraturan Pemerintah No. 42 Tahun 2007 tentang Waralaba. Prosiding Ilmu Hukum, 4(2), 914920. 